\title{
Biological aspects of the genus Brachistosternus (Bothriuridae) in the Atacama Desert (Chile), with the description of a new type of pedipalp macroseta
}

\author{
Aspectos biológicos del género Brachistosternus (Bothriuridae) en el Desierto de \\ Atacama (Chile), con la descripción de un nuevo tipo de macroseta de los pedipalpos
}

\author{
Andrés A. Ojanguren-Affilastro ${ }^{1 *}$, Ricardo Botero-Trujlllo ${ }^{1}$, Alberto Castex² \& Jaime Pizarro- \\ ARAYA ${ }^{3,4}$ \\ 1División Aracnología, Museo Argentino de Ciencias Naturales "Bernardino Rivadavia", Av. Ángel Gallardo 470, C1405DJR, \\ Buenos Aires, Argentina. \\ ${ }^{2}$ Fotografía \& Editorial, http://monoclope.cl/ La Serena, Chile \\ ${ }^{3}$ Laboratorio de Entomología Ecológica, Departamento de Biología, Facultad de Ciencias, Universidad de La Serena, Casilla \\ 554, La Serena, Chile \\ ${ }^{4}$ Instituto de Investigación Multidisciplinar en Ciencia y Tecnología, Universidad de La Serena, La Serena, Chile \\ *E-mail: andres.ojanguren@gmail.com
}

\begin{abstract}
New data about several aspects of the biology of scorpions of genus Brachistosternus of the Atacama Desert are provided. Predatory techniques on tenebrionid larvae, and large spiders in their burrows are described, as well as the method used to transport large preys. The habitat of Brachistosternus mattonii Ojanguren-Affilastro 2005, by the tide line, is described for the first time. Finally a new type of pedipalp macroseta of Bothriuridae is described.
\end{abstract}

Keywords: Scorpiones, Brachistosternus, Atacama, predation, macroseta.

\section{RESUMEN}

Se presentan nuevos datos sobre distintos aspectos de la biología de los escorpiones del género Brachistosternus del desierto de Atacama. Se describen las técnicas predatorias sobre las larvas de tenebriónidos y sobre grandes arañas en sus túneles, así como el método utilizado para transportar grandes presas. El hábitat de Brachistosternus mattonii OjangurenAffilastro 2005, a lo largo de la línea de marea, es descripto por primera vez. Finalmente un nuevo tipo de macroseta de los pedipalpos de Bothriuridae es descripto.

Palabras clave: Scorpiones, Brachistosternus, Atacama, predación, macroseta.

\section{INTRODUCTION}

Most aspects of scorpion behavior and biology are still poorly understood. Many behavioral aspects cannot be observed in captivity because they are direct responses to environmental events that can hardly be reproduced under laboratory conditions. Additionally several scorpion species, as those of the genus Brachistosternus Pocock 1893, are extremely vagile, and very sensitive to laboratory conditions; therefore keeping them in captivity is a difficult task. These methodological restrictions have limited the behavioral studies on this group (Kovařík \& Ojanguren-Affilastro 2013).
Most ecological and behavioral studies on scorpions have been conducted in species from the northern hemisphere (Williams 1966, 1969; Polis 1979; Polis \& Farley 1979; Armas 1980). Only in recent years some contributions dealing with some aspects of the biology (Peretti \& Carrera 2005; Yamaguti \& Pinto Da Rocha 2006; Pizarro-Araya et al. 2011) and ecology of neotropical scorpions have been put forward (Nime et al. 2013, 2014, 2016, Pizarro-Araya et al. 2014).

During the last 15 years we have performed several collection campaigns to the deserts of Northern Chile to study the taxonomy and systematics of the scorpion fauna of the 
region. During field work, we have observed several aspects of the scorpion behavior and ecology that, to our knowledge, have not been documented before in the literature of the group. In this contribution we describe, and photographically document, some predatory behaviors that we could directly observe in the field. We also describe for the first time the microhabitat of Brachistosternus mattonii OjangurenAffilastro 2005, one which was not known to be occupied by any other scorpion in the region, nor by any other congeneric species. Finally, we describe a type of pedipalp macroseta not thus far known in any scorpion group.

\section{METHODS}

Personally collected material studied here was located and captured manually by ultraviolet (UV) light detection at night using UV LEDs inserted into MagliteR 3D flashlights, and pitfall traps. Digital images of scorpions in the field were taken using diverse digital cameras in a period of more than 10 years. Scanning electron micrographs (SEM) were taken with a Philips XL30 TMP SEM at the MACN. Samples for SEM were dehydrated and coated with gold-palladium in a Thermo VG Scientific SC 7620 sputter coater. Voucher specimens of SEM images are deposited at the "Colección Aracnológica del Museo Argentino de Ciencias Naturales Bernardino Rivadavia (MACN-Ar)".

\section{RESULTS AND DISCUSSION}

Predatory behavior on tenebrionid larvae

Scorpions of the genus Brachistosternus and bothriurids in general, are generalist predators which feed on every available prey that they can capture, including small vertebrates (Fulvio-Perez \& Avila 2010; Fulvio-Perez \& Minoli 2014). However, we have observed that in the Chilean Coastal Desert most of their preys are Tenebrionid beetles (Fig. 1b), and particularly their larvae (Fig. 1c). We were intrigued by the way scorpions managed to capture these larvae, since they spend most of their life buried few centimeters under the surface, apparently out of the range of scorpions. The typical predation posture of large specimens of Brachistosternus consists in laying on the soil close to their burrows with their chelae slightly opened in a typical sit-and-wait hunting position. On the other hand, small specimens, particularly juveniles, usually hunt while climbing over grass bristles or twigs of bushes, with their chelae extending upwards (Figs. 1a, d), as reported by Nime et al. (2016). However, in recent campaigns we have repeatedly observed specimens of Brachistosternus introducing the tip of their chelae on the upper loose layer of the substratum (most usually a mix of sand and clay), in what we consider is a technique for hunting tenebrionid larvae and other burrowing preys (Fig. 1e). As far as we know, this is the first time that this kind of hunting technique of burrowed preys is reported in scorpions. Chemoreceptors and mechanoreceptors placed on the external and internal surfaces of the pedipalp fingers (Figs. 2a-d) might take part in this predatory behavior, aside those already known from other parts of the body (Brownell \& Farley 1979). In Brachistosternus these receptors are much more abundant near the tip of the fingers (Figs. 2b, d), whereas the trichobothria, which are sensitive to air movements and would collapse if introduced under the substrate, are absent from the apical third of the fingers (Fig. 2c). We have observed that in deserticolous genera of Bothriuridae such as Brachistosternus and Timogenes Simon 1880, these apical receptors are much more abundant than in other genera from mesic environments like Phoniocercus Pocock 1893 and Urophonius Pocock 1893.

Bub \& Bowerman (1979) described a pedipalp cleaning behavior which occurs after they capture a prey, and which they called "sand thrust behavior". This cleaning technique partially resembles the hunting technique that we describe herein, in that the scorpions introduce their chelae in the sand. However we do not consider that both techniques are related, since in the sand thrust behavior the scorpion introduces one chela at the time, and moves it in a clear cleaning behavior (Jiao \& Zhu 2009), while with the other chela they grab the prey that they are eating. In contrast, in our case the scorpion gently introduces both chelae into the substrate at the same time, and we have not observed any scorpion doing this while they were eating, nor have we observed them performing any evident cleaning movement.

Lowe \& Kovařík (2016) and Kovařík et al. (2016) mention that several Buthids from the arid areas of the Horn of Africa also forage on tenebrionid larvae in their burrows. However the hunting technique that they observed is different since in that case, those larvae were predators, and not detritivorous as those that we observed in the Pacific coastal desert; those African larvae were captured in burrows at the bottom of funnels in sand, similar to those of ant lion larvae (Myrmeleontidae) (Lowe \& Kovař́k 2016; Kovařík et al. 2016).

\section{PREDATION ON SPIDERS IN THEIR TUNNELS}

Another interesting predatory behavior of Brachistosternus that we observed in the field was the active predation of large burrower spiders (most probably of the families Nemesiidae and Lycosidae) in their tunnels. In order to do this, the scorpion introduces most of its body in the tunnel, except for the fourth pair of legs and the terminal segments of the metasoma (Fig. 1f), which are used to eventually lever up their body and get out of the spider's tunnel. We have observed a very similar behavior in Urophonius tumbensis Cekalovic 1981 entering into the tunnels of spiders of genus Ariadna Audouin 1826 (Segestriidae), in the bark of the trees, in the wet cold woodlands of Patagonia (PizarroAraya et al. 2011). 


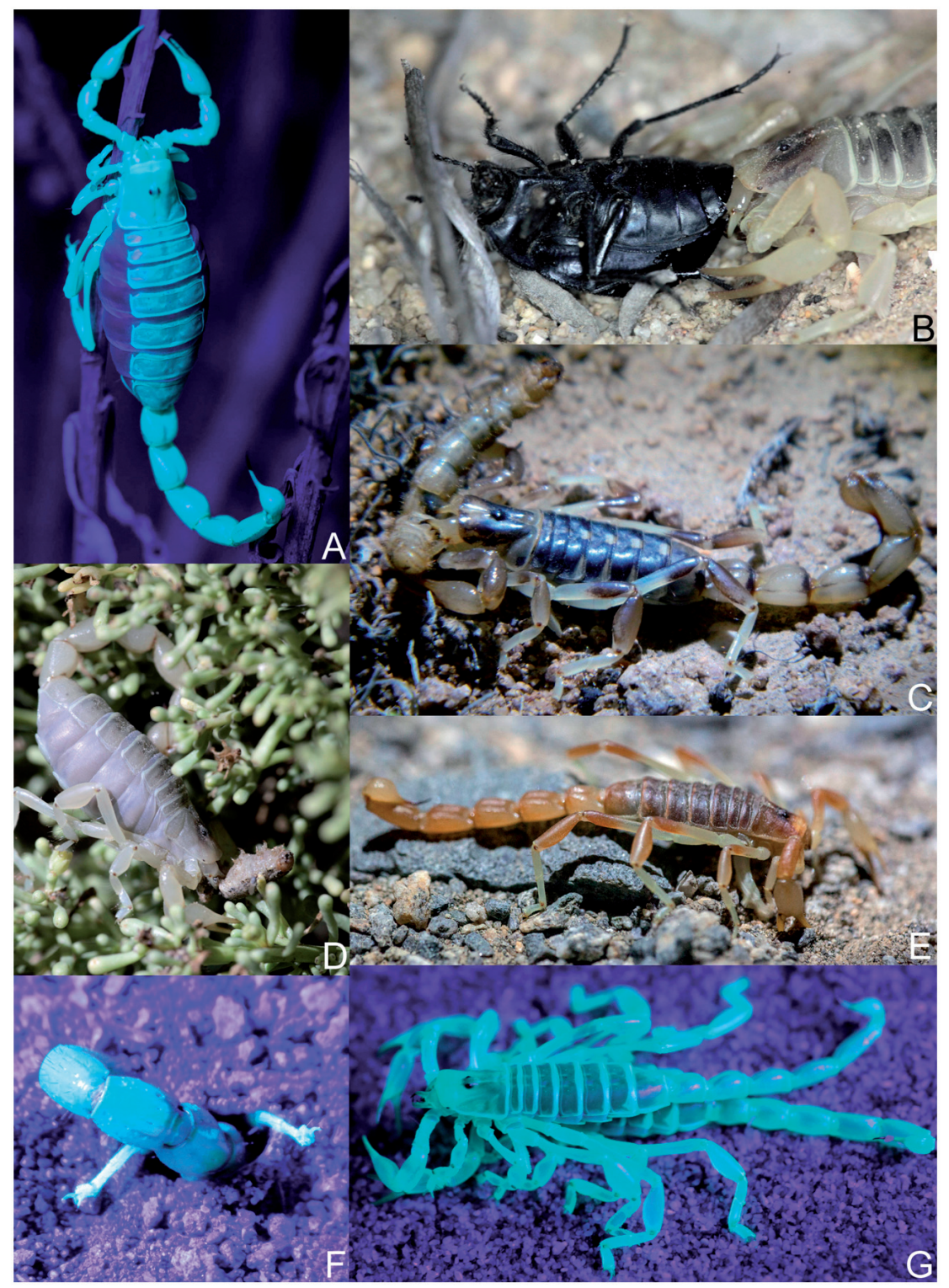

Figure 1. A) Juvenile of Brachistosternus sp. climbing on grass bristles, Llanos de Challe National Park, Atacama region, Chile. B) Adult male of Brachistosternus paposo Ojanguren-Affilastro \& Pizarro-Araya 2014 feeding on an adult female of Gyriosomus kingi Reed 1873 (Tenebrionidae), Llanos de Challe National Park, Atacama region, Chile. C) Adult female of Brachistosternus cekalovici OjangurenAffilastro 2005 feeding on a larva of Gyriosomus luczotii Laporte 1840 (Tenebrionidae), Cuesta Porotitos, Coquimbo region, Chile. D) Juvenile of Brachistosternus sp. feeding on a larva of noctuid (Lepidoptera) while climbing on the branches of a Crassulaceae bush. E) Adult male of Brachistosternus mattonii Ojanguren-Affilastro 2005 introducing the tip of its pedipalps into the upper layer of sandy soil, Morro Moreno National Park, Antofagasta region, Chile. F) Brachistosternus cekalovici entering in the tunnel of a funnel web spider, Fray Jorge National Park, Coquimbo region, Chile. G) Juvenile of Brachistosternus sciosciae Ojanguren-Affilastro 2002 transporting a dead con-specific prey of its same size over its body, Llanos de Challe National Park, Atacama region, Chile.

Figura 1. A) Juvenil de Brachistosternus sp. trepado sobre ramas, Parque Nacional Llanos de Challe, Región de Atacama, Chile. B) Macho adulto de Brachistosternus paposo Ojanguren-Affilastro \& Pizarro-Araya 2014 alimentándose de una hembra adulta de Gyriosomus kingi Reed 1873 (Tenebrionidae), Parque Nacional Llanos de Challe, Región de Atacama, Chile. C) Hembra adulta de Brachistosternus cekalovici Ojanguren-Affilastro 2005 alimentándose de una larva de Gyriosomus luczotii Laporte 1840 (Tenebrionidae), Punta Teatinos, Región de Coquimbo, Chile. D) Juvenil de Brachistosternus sp. trepado sobre ramas de una crasulácea y alimentándose de una larva de noctuido (Lepidoptera). E) Macho adulto de Brachistosternus mattonii Ojanguren-Affilastro 2005 introduciendo la punta de sus pedipalpos dentro de la capa superior de sustrato arenoso, Parque Nacional Morro Moreno, Región de Antofagasta, Chile. F) Brachistosternus cekalovici entrando en el túnel de una araña cavadora, Parque Nacional Fray Jorge, Región de Coquimbo, Chile. G) Juvenil de Brachistosternus sciosciae Ojanguren-Affilastro 2002 transportando una presa co-específica de su mismo tamaño, sobre su cuerpo, Parque Nacional Llanos de Challe, Región de Atacama, Chile. 


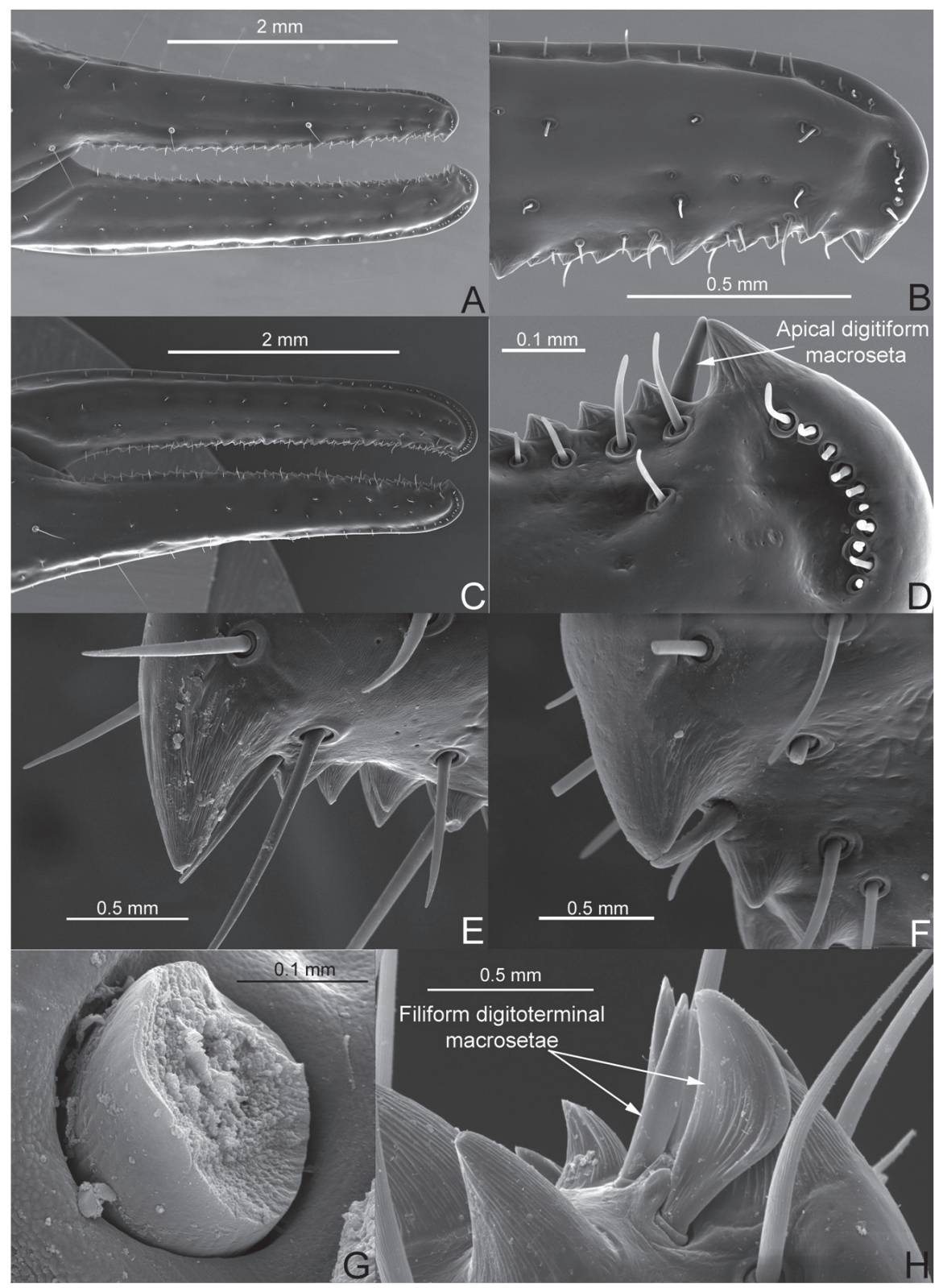

Figure 2. SEM photos. A) Brachistosternus mattonii Ojanguren-Affilastro 2005 external surface of the pedipalp fingers. B) Brachistosternus mattonii, detail of external surface the tip of the fixed pedipalp finger, showing the apical digitiform macroseta and the constellation array. C) Brachistosternus mattonii, internal surface of the pedipalp fingers. D) Brachistosternus mattonii, detail of external surface the tip of the movable pedipalp finger, showing the apical digitiform macroseta. E) Phoniocercus sp. detail of internal surface the tip of the fixed pedipalp finger, showing the apical digitiform macroseta. F) Rumikiru lourencoi Ojanguren-Affilastro 2003 (Bothriuridae), detail of internal surface the tip of the fixed pedipalp finger, showing the apical digitiform macroseta. G) Brachistosternus multidentatus Maury 1984, detail of a broken apical digitiform macroseta (note that there is no hollow). H) Tityus confluens Borelli 1899 (Buthidae), detail of the internal margin of the movable finger of the pedipalp showing the apical macrosetae.

Figura 2. Fotos de MEB. A) Brachistosternus mattonii Ojanguren-Affilastro 2005 superficie externa de los dedos de los pedipalpos. B) Brachistosternus mattonii, detalle de la superficie externa de la punta del dedo fijo del pedipalpo, mostrando la macroseta digitiforme y el "costellation array". C) Brachistosternus mattonii, superficie interna de los dedos de los pedipalpos. D) Brachistosternus mattonii, detalle de la superficie externa de la punta del dedo móvil del pedipalpo, mostrando la macroseta apical digitiforme. E) Phoniocercus sp. detalle de la superficie interna de la punta del dedo fijo del pedipalpo, mostrando la macroseta apical digitiforme. F) Rumikiru lourencoi Ojanguren-Affilastro 2003 (Bothriuridae), detalle de la superficie interna de la punta del dedo fijo del pedipalpo, mostrando la macroseta apical digitiforme. G) Brachistosternus multidentatus Maury 1984, detalle de una macroseta digitiforme apical rota (nótese que no es hueca). H) Tityus confluens Borelli 1899 (Buthidae), detalle de la superficie interna de la punta del dedo móvil del pedipalpo, mostrando las macrosetas apicales. 
TRANSPORT OF PREYS

We have observed that after capturing large preys the scorpions of the genus Brachistosternus sometimes do not feed on them on the spot, but transport them to another place. In order to do this, the scorpion grabs the dead prey with its chelicerae and places it on the top of its carapace. When transporting particularly large preys, such as con-specifics of the same cohort, the prey is placed over the carapace and tergites (Fig. 1g). An identical transport behavior of large preys was observed, (to our knowledge for the first time in the order), by Lowe \& Kovařík (2016) in Neobuthus awashensis Kovařík \& Lowe, 2012, and by Kovařík et al. (2016) in Parabuthus pallidus (Pocock 1895), both of family Buthidae, which demonstrates that this transport behavior is not unique to Brachistosternus.

\section{HABITAT OF BRACHISTOSTERNUS MATTONII}

Brachistosternus mattonii was originally described on the basis of specimens collected by Maury and Roig-Alsina during the decade of 1980 (Ojanguren-Affilastro 2005) in Hornitos (2255'7.00'S; 70¹7'29.54' W), in coastal areas of Antofagasta region, Chile. The original label accompanying these materials was quite complete, but it did not specify the particular microhabitat where these specimens were collected. Two posterior collection campaigns by the first author to the type locality were unsuccessful. It should be noted that the type locality has experienced an important urbanistic development during the last forty years, causing a major modification in most of the original environment of the area. Therefore, we could not draw any conclusions about the microhabitat preferred by this species from our campaigns.

In a recent collection expedition to Antofagasta region, we identified a population of $B$. mattonii in the coast of Mejillones Peninsula, near Morro Moreno National Park (2328'30.7's; $\left.70^{\circ} 36^{\prime} 36.5^{\prime \prime} \mathrm{W}\right)$. Thanks to this, we could find out that this species occurs in the sea shore, by the tide line. This is the first species of Brachistosternus that has been registered in such environment.

The area where this species occurs is an absolute desert, with one of the lowest rates of rainfall in the world (Rundel et al. 1991). Due to this, species of epigean arthropods of the area only occur in the few places which can sustain some vegetation, or retain some humidity (Cepeda-Pizarro et al. 2005). Scorpions of the absolute desert of northern Chile and southern Peru, have thus far only been collected in the ravines of the few rivers that originate in the Andes (Ochoa \& Ojanguren-Affilastro 2007), or on the slopes of the coastal mountain chain that concentrate some sea fog, allowing the presence of a Lomas environment (Ojanguren-Affilastro et al. 2007; Ojanguren-Affilastro \& Pizarro-Araya 2014). This is the first documented case of exploitation of the tide line environment by a scorpion species in the area. Unfortunately we could not find the galleries of these scorpions to check out if they remained under the water during the high tide. Up to now the only Neotropical scorpion species that was mentioned to use this kind of micro-habitat was Bothriurus burmeisteri Kraepelin 1894, specimens of which have been found under dry algae debris in the coast of Argentinian Patagonia (Maury 1979). However, B. burmeisteri is a very abundant, generalist species that occurs in many different micro-habitats, from the slopes of the Andes to the coast. There are some other scarce previous records of scorpions using this kind of habitat (Remy \& Leroy 1933; Due \& Polis 1985), but they all belong to other families, and inhabit in other biogeographic realms.

We have observed that $B$. mattonii feeds on larvae of the psammophilus tenebrionid Phaleria gayi Laporte 1840. Larvae and adults of genus Phaleria have a detritivorous diet associated to the algae and organic mater that accumulates in the tide line. This tenebrionid genus is also present in the seashore of Atacama and Coquimbo regions; however, no species of Brachistosternus of these regions have been observed feeding on them. Apparently, in the extreme harsh conditions of the coast of the hyper arid desert of Antofagasta, the scarce food sources for large invertebrate predators are mostly limited to the tide line.

APICAL DIGITIFORM MACROSETA

Among the different setae observed in the scorpion chelae, we have registered for the first time the presence of a thick apical digitiform macroseta, leaning on the internal margin of the apical tooth of the median internal row of denticles (Figs. $2 \mathrm{~b}, \mathrm{~d}$ ). We have revised specimens belonging to all the genera of Bothriuridae (except Brandberghia Prendini 2000), and observed that this apical macroseta is present in all the studied genera of the family, with slight morphological differences between genera and species (Figs. 2e, f). It is a very thick seta without internal hollow (Fig. $2 \mathrm{~g}$ ), which may serve a structural or protecting function, or may be a mechanoreceptor associated to the apical denticle. This digitiform macroseta resembles, up to some extent, the "filiform digitoterminal" macrosetae of Buthidae (Fig. 2h) (Cruz \& Armas 1980).

\section{ACKNOWLEDGEMENTS}

Our acknowledgements to CONAF for helping us by providing permission and facilities to work in the SNASPE areas (Projects N. 006/2014 and 028/2015). We thank Fermín M. Alfaro, Juan Enrique Barriga, Hernán A. Iuri, Pablo Agusto, Andrés Porta, and Cristian Rivera (Chañaral island, CONAF, Atacama), for assisting us in the field. We thank Camilo Mattoni and an anonymous reviewer that revised and improved an early version of this manuscript. This study was funded by grants from DIULS and PR15121/VACDDI001 
projects of the University of La Serena, La Serena, Chile (JPA), PIP 2010-1764 and iBOL Argentina (2012) to AAOA, and a Doctoral grant of CONICET to RBT.

\section{BIBLIOGRAPHY}

Armas, L.F. 1980. Aspectos de la biología de algunos escorpiones cubanos. Poeyana 211:1-28.

Brownell, P. \& Farley, D. 1979. Prey localization behavior of the nocturnal scorpion Paruroctonus mesaensis: orientation to substrate vibrations. Animal Behaviour 27: 185-193.

Bub, K. \& Bowerman, R.F. 1979. Prey capture by the scorpion Hadrurus arizonensis Ewing (Scorpiones: Vaejovidae). Journal of Arachnology 7(1):243-53.

Cepeda-Pizarro, J., Pizarro-Araya, J. \& Vásquez, H. 2005. Variación en la abundancia de la artrópodofauna, con énfasis en tenebriónidos epígeos, del desierto costero transicional de Chile. Revista Chilena de Historia Natural 78:651-663.

Cruz, J. \& Armas, L.F. 1980. Macroquetas digitales en Buthidae (Arachnida: Scorpionida). Poeyana 199:1-10.

Due, A.D. \& Polis, G.A. 1985. Biology of the intertidal scorpion, Vaejovis littoralis. Journal of Zoology, London 207:563-580.

Fulvio-Pérez, Ch. \& Minoli, I. 2014. Depredación de Homonota darwinii Laurent 1984 (Squamata: Phyllodactylidae) por Brothriurus burmeisteri Kraepelin, 1894 (Scorpiones: Bothriuridae) en la provincia del Chubut, Argentina. Cuadernos de Herpetología 28 (2):1-2.

Fulvio-Pérez, Ch. \& Ávila, L.J. 2016. Predation of Liolaemus huacahuasicus (Squamata: Iguania: Liolaemini) by Brachistosternus intermedius (Scorpiones: Bothriuridae) in Cumbres Calchaquíes, Tucumán province, Northwestern Argentina. Cuadernos de Herpetología 24 (2):123-124.

JiAO, G.B. \& ZHU, M.S. 2010. Cleaning behaviors in four scorpion species. Journal of Venomous Animal Toxin, including Tropical Deceases 16 (2):375-381.

Kovařík, F. \& OJanguren-Affilastro, A.A. 2013. Illustrated catalog of scorpions. Part II. Bothriuridae; Chaerilidae; Buthidae I., genera Compsobuthus, Hottentotta, Isometrus, Lychas, and Sassanidotus. Jakub Rolčík Publisher, Czech Republic, 400 pp.

KovaŘíí, F., Lowe, G., Plíǐková, J., \& ŠŤÁhlavskÝ, F. 2016. Scorpions of the Horn of Africa (Arachnida, Scorpiones). Part VII. Parabuthus Pocock, 1890 (Buthidae) with description of $P$. hamar sp. n. and P. kajibu sp. n. from Ethiopia. Euscorpius 228:1-58.

Lowe, G. \& KovaŘík, F. 2016. Scorpions of the Horn of Africa (Arachnida, Scorpiones). Part V. Two new species of Neobuthus Hirst, 1911 (Buthidae), from Ethiopia and Eritrea. Euscorpius 224:1-46.

MAURY, E.A. 1979. Apuntes para una zoogeografía de la ecorpiofauna argentina. Acta Zoológica Lilloana 35:703-719.

Nime, M.F., Casanoves, F. \& Mattoni, C.I. 2014. Scorpion diversity in two different habitats in the Arid Chaco, Argentina. Journal of Insect Conservation 18:373-384.

Nime, M.F., Casanoves, F. \& Mattoni, C.I. 2016. Microhabitat use and behavior differ across sex-age classes in the scorpion Brachistosternus ferrugineus (Scorpiones: Bothriuridae). Journal of Arachnology 44:235-244.
Nime, M.F., Casanoves, F., Vrech, D.E. \& Mattoni, C.I. 2013. Relationship between environmental variables and surface activity of scorpions in the Arid Chaco ecoregion of Argentina. Invertebrate Biology 132 (2): 145-155.

Ochoa, J.A. \& Ojanguren-Affilastro, A.A. 2007. Systematics and distribution of Brachistosternus (Brachistosternus) ehrenbergii (Gervais, 1841), with the first record of stridulation in the genus Brachistosternus. Studies on Neotropical Fauna and Environment 42 (1): 61-69.

Ojanguren-Affilastro, A.A. 2005. New data about the genus Brachistosternus in Chile, with the description of two new species. (Scorpiones, Bothriuridae). Journal of Arachnology 33: 175-192.

Ojanguren-Affilastro, A.A., Mattoni, C.I. \& Prendini, L. 2007. The genus Brachistosternus in Chile (Scorpiones: Bothriuridae), with the description of two new species. American Museum Novitates 3564: 1-44.

Ojanguren-Affilastro, A.A. \& Pizarro-Araya, J. 2014. Two new scorpion species from Paposo, in the Coastal desert of Taltal, Chile (Scorpiones, Bothriuridae, Brachistosternus). Zootaxa 3785 (3): 400-418.

Peretti, A.V. \& Carrera, P. 2005. Female control of mating sequences in the mountain scorpion Zabius fuscus: males do not use coercion as a response to unreceptive females. Animal Behaviour 69: 453-462.

Pizarro-Araya, J., Ojanguren-Affilastro, A.A. \& Prendini, L. 2011. First report of an arboreal bothriurid (Scorpiones: Bothriuridae) from the temperate forests of southern Chile. Gayana 62 (2): 166-170.

Pizarro-Araya, J., Agusto, P., López-Cortes, F., OjangurenAffilastro, A.A., Briones, R. \& Cepeda-Pizarro, J. 2014. Diversidad y composición estacional de la escorpiofauna (Arachnida: Scorpiones) del archipiélago Los Choros (Región de Coquimbo, Chile). Gayana 78 (1): 46-56.

Polis, G.A. 1979. Prey and feeding phenology of the desert sand scorpion Paruroctonus mesaensis (Scorpionida, Vaejovidae). Journal of Zoology 188: 333-346.

Polis, G.A. \& Farley, R.D. 1979. Behavior and ecology of mating in the cannibalistic scorpion Paruroctonus mesaensis Stahnke (Scorpionida: Vaejovidae). Journal of Arachnology 7: 33-46.

Remy, P. \& Leroy, P. 1933. Présence de Scorpions dans la zone subterrestre du littoral marin. Bulletin Mensuel Société Linnéenne de Lyon 2(3): 3-42.

Rundel, P.W., Dillon, M.O., Palma, B., Mooney, H., Gulmon, S.L. \& EhLERINGER, J.R. 1991. The phytogeography and ecology of the coastal Atacama and Peruvian deserts. Aliso 13:1-50.

Yamaguti, H. \& Pinto Da Rocha, R. 2006. Ecology of Thetylus aurantiurus of the Parque Estadual da Serra da Cantareira, Sao Paulo, Brazil (Scorpiones, Bothriuridae). Journal of Arachnology 34: 214-220.

Williams, S.C. 1966. Burrowing activities of the scorpion Anuroctonus phaeodactylus Wood (Scorpionida: Vaejovidae). Proceedings of the California Academy of Sciences 34: 419-428.

Williams, S.C. 1969. Birth activities of some North American scorpions. Proceedings of the California Academy of Sciences 37 (1): 1-24.

Recibido: 29.08.16

Aceptado: 25.10 .16 